\title{
The EU and Southern Cross: The effects of EU energy policy on EU-Australia energy trade
}

\author{
EVAN THOMPSON \\ Monash European and EU Centre \\ evan.thompson@monash.edu
}

\begin{abstract}
The Lisbon Treaty which entered into force in 2009 was a major event in the ongoing evolution of the European Union (EU) project. However, despite important changes, energy policy formation remains muddled and continues to be area of contest between the EU and its Member States. This in turn means that trade dynamics with important energy providers such as Australia become affected by the internal dynamics concerning energy policy within the EU. Complicating this further is the advancement of climate change mitigation as a major policy issue also has wide ranging implications.

The article argues that despite the Lisbon Treaty providing a legal basis for formulating energy policy through the application of shared competences, it does not exercise any substantive direct influence on national or trade-related issues surrounding energy. Instead of the EU exercising relative control, trade in energy resources is still conducted largely on a bilateral basis with EU Member States continuing to determine the primary aspects of their energy policy. As such, the greatest impact the EU has on Member State-Australia's energy trade is indirect, through binding policy initiatives originally negotiated by the Member States.
\end{abstract}

Key Words: Australia, European Union, Member State, Climate and Energy Package, Energy, Trade Policy, Coal, Uranium, Natural Gas

\section{Introduction}

The Lisbon Treaty which entered into force in 2009 was a major event in the ongoing evolution of the European Union (EU) project. It involved the consolidation of the European Communities (EC) treaties, the establishment of the Presidency of the European Council and the High Representative for External Affairs, and the establishment of a pan-EU diplomatic service - the European External Action Service (EEAS) - to represent the EU on the global stage. It also saw a clearer delineation of responsibilities between the EU institutions (particularly the EU Commission) and the Member States through a more thorough division of 'competences' on a wide range of policy areas. However, despite these important changes, energy policy formation remains muddled and continues to be area of contest between the EU and its Member 
States. This in turn means that trade dynamics with important energy providers such as Australia become affected by the internal dynamics concerning energy policy within the EU. The development climate change as a major policy issue also has wide ranging implications. The analysis of EU-Australia trade typically draw on issues surrounding the EU's Common Agricultural Policy (CAP) and the frictions this causes in the relationship. Relatively little scholarly analysis has yet been done on the energy trade as compared to agriculture. This article seeks to address this in part.

The article first seeks to provide a means of understanding current the EU dynamics for determining EU energy policy in the post-Lisbon era. In doing so, it will identify the complexity of formulating EU energy policy and demonstrate that because energy resources are both strategic in nature and largely imported into the EU, Member States retain control of policy matters. This is despite the fact that energy has been included in the Lisbon Treaty as an area of 'shared competence' between the EU Commission and the Member States. This article highlights how the EU exercises competence and authority over certain areas of energy policy relating to competition and climate change, which influences how Member States determine their own overall policy, in particular their approach to their energy mix. The second part of the article examines the basis of EU-Australia trade and current dynamics using Australia-EU trade data. The third section draws on the previous two parts to analyse how the dynamics in EU energy policy then affects these energy-based trade relations, concentrating particularly on the ramifications of the Climate and Energy Package (CEP).

The article argues that despite the Lisbon Treaty providing a legal basis for formulating energy policy through the application of shared competences, it does not exercise any substantive influence on national or trade-related issues surrounding energy. Instead of the EU exercising relative control, trade in energy resources is still conducted largely on a bilateral basis. EU Member States continue to determine the primary aspects of their energy policy. The greatest impact of these recent EU developments on Australia's exports of energy resources is indirect, through binding policy initiatives originally negotiated by the Member States. This is particularly well demonstrated by the CEP and in particular it's 20-20-20 targets which are stimulating a shift towards renewable energy on the part of state governments. As such, it is the decisions of the Member States in response to these changes which have the most impact on the energy trade relationship between the EU and Australia.

\section{EU Energy Policy Post Lisbon}

The central role that energy plays within society means that it has tended to be the subject of much greater government control than is otherwise seen in states which adhere to liberal market principles, such as those in the EU or Australia. Furthermore, energy policy links with numerous other policy areas including trade, environment, and even foreign and security policy. Concerns about nuclear power and the potential for nuclear proliferation is a clear case in point. This makes energy policy an area of inherent complexity, both in its formulation and application. In the EU, this is 
compounded further as there are a number of factors at play which further complicate attempts to develop an EU energy policy.

Even though the EU was in large part built on the basis of energy and industrial cooperation through its predecessor the European Coal and Steel Community (ECSC) and the European Atomic Energy Community (EURATOM), energy policy as a distinct issue was not included in either the Treaties of Paris or Rome. Indeed, energy was only recently introduced with the Lisbon Treaty, where it became a specific subject within the scope of the EC treaties. ${ }^{1}$ Although it introduced many changes in the structure and function of the EU, ${ }^{2}$ the Lisbon Treaty did not grant any new exclusive competences to the EU institutions. Instead it introduced a more expansive array of shared competences with member-state governments, including for the first time in the area of energy. ${ }^{3}$

Importantly, however this has not actually clarified energy policy leadership, and although the allocation of energy as a shared competence seems clear-cut this is not in fact the case. Given the link between energy policy and many other policy areas the move to allocate energy as a shared competence has not provided any substantive clarity on whether the EU Commission or Member States are responsible for leadership. . This lack of clarity is further exacerbated by the fact that energy policy coincides with other fields which are themselves subject to varied competency arrangements. For instance, the EU and Member States share competence in regards to the functioning of the Internal Market and trans-European networks (which include energy infrastructure). ${ }^{4}$ However, the EU retains exclusive competence on the Customs Union issues, thereby exercising important controls regarding EU trade with third countries. ${ }^{5}$ Simultaneously, Member States continue to have dominance over security and foreign policy affairs. This has been maintained through these areas' omission from the categories of exclusive or shared competences and the intergovernmental system in place for the Common Foreign and Security Policy (CFSP). Thus, in demonstrating the array of policy areas which all relate to energy policy to a certain extent, it becomes clear that the decisionmaking process for energy issues is particularly ambiguous. Additionally, with the EU energy import dependence in 2009 reaching $83.5 \%$ for oil and $64.2 \%$ for gas, foreign

1 Commission of the European Communities, Consolidated Version of the Treaty on the Functioning of the European Union, Luxembourg: Publications Office of the European Union (2010): Article 194.

2 The decision-making process of the EU has undergone important changes with the entering into force of the Lisbon Treaty. The Council of Ministers are the primary body for formulating European Laws and endorsing policy through the 'double majority' system. The double majority system requires that a 55\% of EU members representing $65 \%$ of the population endorse the measure, with the votes for each state attributed according to their demographic weight. The European Parliament enjoys co-legislative authority with the Council of Ministers, approving the European Union budget and laws and is elected by universal suffrage. The European Commission acts as the executive body of the European Union, implementing common policy and member-state adherence to the Treaties. It also proposes Directives and regulations to the legislative bodies and upon their adoption works to enforce them.

3 Ibid. Article 4.

4 Commission of the European Communities, Treaty on the Functioning of the European Union, op.cit.: Article 4.

5 Commission of the European Communities, Treaty on the Functioning of the European Union, op.cit.: Article 3. 
policy especially becomes an integral component of energy issues. 6 This needs to be given particular consideration. As foreign policy is an element of statehood, the role of the EU in this context is particularly difficult to establish. The EU is not a state but it does act much like one at the international level, especially in relation to trade. This is particularly evident through its seat at the World Trade Organisation (WTO) and its conclusion of a series of bilateral agreements with non-EU countries. However, on other issues of foreign policy, its powers do not extend very far, particularly where it relates to security issues. Although the Lisbon Treaty in essence established an EU diplomatic corps (the EEAS) it does not confer sovereignty from Member States to the EU on foreign policy issues. Instead, Member States continue to exercise sovereignty and control of EU foreign policy through the workings of the European Council. One could argue that the CFSP and the position of the High Representative (introduced in the Lisbon Treaty and currently held by Baroness Catherine Ashton), are examples of the EU accompanying the Member States as an actor on foreign and security policy. However, this is not in fact the case. The CFSP .particularly in the areas of military and defense, requires unanimity amongst the Member States and therefore the High Representative cannot articulate a common position where requisite agreement is lacking. ${ }^{7}$ This was demonstrated in the EU's slow response to the events of the Arab Spring and the military intervention in Libya When military intervention did occur in Libya it was undertaken in large part by the United Kingdom and France under the auspices of NATO enforcing a United Nations Security Council Resolution. ${ }^{8}$ Germany refused to be involved, despite being a co-member of both the EU and NATO. ${ }^{9}$ The fact that the EU was not able to act while NATO was able to respond even in the face of German resistance shows the EU's lack of capacity to respond to in security and foreign policy events when unanimity has not been reached. This is particularly relevant to energy security issues as these are typically sensitive policy areas in the EU. The EU's capacity to function as an actor alongside the Member States is extremely limited in this domain. However, once one accounts for recent energy policy initiatives of a more market-oriented as opposed to security-based nature, a more nuanced dynamic emerges.

The recent release of the 'Energy Policy for Europe' (EPE) in 2007 by the EU Commission has been one of the most important steps in developing an energy policy on an EU scale that reflects the development of EU interests as opposed to purely national ones. The EPE however lacks the foundations for effective implementation, as it still

6 Eurostat, Energy Dependence,

http:/ / epp.eurostat.ec.europa.eu/tgm/ table.do?tab=table\&init=1\&plugin=1\&language=en\&pcode=tsdcc3 10, accessed 28 November, 2011.

7 Commission of the European Communities, Consolidated Version of the Treaty on European Union,

Luxembourg: Publications Office of the European Union (2010): Articles 24-31.

8 BBC News, Libya: US, UK and France Attack Gaddafi Forces, BBC, 20th March, 2011,

<http:// www.bbc.co.uk/ news/ world-africa-12796972>, accessed 29 November, 2011; Ian Black, UK and

France dismiss Italy's call for pause in Nato bombing of Libya, The Guardian, 22nd J une, 2011,

$<$ http:// www.guardian.co.uk/ world/2011/jun/22/libya-nato-bombing-uk-france-italy>, accessed 29

November, 2011.

9 Steven Erlanger and J udy Dempsey, Germany Steps Away from European Unity, New York Times, 23rd March, 2011. <http:// www.nytimes.com/2011/ 03/24/ world/ europe/ 24germany.html?pagewanted=all>. accessed 29 November, 2011. 
requires external measures, which come under the competence of the individual Member States. The problems relating to the formation and implementation of the external aspects of energy policy have been noted in various works including those by Dieter Helm (The Russian Dimension and Europe's external energy policy), Coby van der Linde (Turning a Weakness into a Strength: A Smart External Energy Policy) amongst others. Notably the strain of analysis demonstrates that it is the ongoing capacity and inclination for Member States to act unilaterally on energy interests which undermines the process of a true EU energy policy emerging. ${ }^{10}$ It is inevitable that states - still bearing legitimacy in issues of foreign and security policy - continue to formulate national interests and act towards the satisfaction of their energy-related interests (potentially at the expense of other Member States' interests) rather than working towards achieving wider EU interests. As Coby van der Linde and J acques de Jong articulate in EU Energy Policy in a supply-constrained world "shared responsibility does not easily transform into a shared interest or view among the 27 member states."11 Thus, competing interests emerge at the Member State level preventing the development of a unified position of the EU on foreign policy and therefore limiting EU agency. This does not apply in all areas however.

Although Member States continue to exercise a great deal of sovereignty in terms of their dealings with third parties on energy security matters, their overall energy policy is also affected by internal developments. The sovereignty of Member States on issues of external dealings may be as yet relatively secure, but the EU Commission does exercise important controls that can impact on state energy policy formation. The competences that the EU enjoys on aspects of competition are an important dynamic which needs to be considered. The introduction of the Third Energy Package (TEP) with its emphasis on liberalisation measures is a case in point.

Prior to the liberalization drive in the EU, the energy industry was an area in which there was little competition, with individual companies undertaking most activities in the market, often with the government as a major shareholder. As the functions of the industry encompassed successive, distinct phases (generation, transmission, distribution, retail) a tendency for the vertical integration of the supply chain under the legal ownership of a single company developed. Gaz de France is a good example of this. ${ }^{12}$ Many of the measures contained within the TEP have been aimed at dismantling these monopolistic and vertically integrated companies. The TEP has sought to do this through the separation of the transmission/distribution and production/supply segments of the energy market chain in a process called 'unbundling' and the

\footnotetext{
10 Dieter Helm, "The Russian Dimension and Europe's external energy policy" <http:// www.dieterhelm.co.uk/ sites/ default/ files/ Russian_dimension.pdf>, accessed 14 May 2011, p. 2.; Coby van der Linde "Turning a Weakness into a Strength: A Smart External Energy Policy," IFRI, April, 2008, 4-11.

11J acques de J ong and Coby van der Linde, "EU energy policy in a supply-constrained world," European Policy Analysis 11, (2008): 6.

12 Peter Duncanson Cameron, "Competition in Energy Markets: Law and Regulation in the European Union, 2nd ed. (Oxford: Oxford University Press, 2007), 9-20.
} 
establishment of Independent Transmission Operators (ITOs). ${ }^{13}$ The TEP is important from a competition and free market perspective, but also in terms of altering memberstate energy policy as it stimulates changes in the structure and functioning of their markets. In areas where it enjoys competence the EU Commission can influence the energy policy formulations of its state and force shifts where it deems them to be necessary. The EU-Australia energy trade is more directly affected by policies which force changes in the energy mix of the countries. For example, the recently adopted climate change policies encapsulated in the CEP are of substantial importance.

Climate change is an inherent part of broad energy policy. It is interwoven into the dynamics informing EU and Member State energy policy formation. Climate change however, is not substantively addressed in the Lisbon Treaty. This means that it is subject to the problematic policy formation currently being experienced regarding energy issues. There does however appear to be a general level of consensus on the need to address climate change. This is in part stimulated by the global attention to climate change and also as strong public awareness of the issue within the EU places greater pressure on governments to be proactive in forming policy on climate change. This is evidenced through the EU's global leadership at forums such as Copenhagen and Cancun and the introduction of the CEP in 2009.

Although it was originally introduced and endorsed at the 2008 session of the European Council, the CEP only entered into force in 2009 after being passed by the European Parliament and European Council. ${ }^{14}$ The CEP pushes for an ambitious set of goals to try and mitigate the EU's contribution to climate change and advances a set of mandatory targets. Thus, the CEP targets (otherwise known as the 20-20-20 targets) have become binding upon the Member States and are forcing a shift in government policy. These goals are threefold: to achieve an EU-wide 20\% reduction of GHGs below 1990 levels by 2020 with the proviso to increase the reduction target to $30 \%$ if the original aim is matched by other developed economies; a $20 \%$ share of renewable sources in final energy consumption; and a $20 \%$ reduction in primary energy use below baseline projections for 2020. ${ }^{15}$ By making such targets into law, the EU has managed to go further on climate change issues than it has on almost all other areas relating to energy policy. It must be stressed that although the CEP was negotiated and agreed to by the 27 Member State governments, there are still ongoing political contests regarding certain aspects. For instance, Poland continues to be highly concerned about the ambitiousness of the emissions reduction target because most of its energy generation is coal-based. Approximately 92\% of Poland's electricity generation in 2004 came from coal, which it can source domestically. ${ }^{16}$ Meeting the reductions targets would be not only an extremely costly project but would necessitate an increase in imports of energy

13 EurActiv, Eight EU states oppose unbundling, table 'third way', 1st February, 2008,

<http:// www.euractiv.com/ energy/ eu-states-oppose-unbundling-table-third-way/ article-170048>, accessed 2 November, 2011.

14 Europa, Commission welcomes adoption of climate and energy package, Press Release RAPID, IP/ 09/628, 23rd April, 2009.

15 Ibid

16 Directorate General for Energy and Transport, Poland - Energy Mix Fact Sheet, $<$ http:// ec.europa.eu/ energy/ energy_policy/doc/ factsheets/mix/mix_pl_en.pdf $>$, accessed: 1 November, 2011. 
resources particularly from Russia. The CEP leaves decisions on energy mix to the Member States only indicating the targets that need to be reached. ${ }^{17}$ However, the fact that the emissions targets necessitate changes in the energy mix demonstrates the constraints on national governments.

The legal nature of the 20-20-20 goals reinforces shifts in energy policy amongst the EU Member States and provides continued impetus for the advancement of climate change policy. Therefore even if the targets themselves are not reached, the existence of binding targets introduced by a series of separate measures and policy orientation on climate change will stimulate important physical changes. Through these changes, the CEP is set to make more wide-ranging impacts on EU energy markets at various levels as it seeks to address climate change within its attempts of broader unified EU energy policy. The impact of the legislation and resultant shifts in energy policy and practice is seen the national level rather than at the EU level. Contrary to the minor carry-on effects from the Lisbon Treaty, the CEP is manifested in domestic legislation and National Action Plans (which must be submitted to the Commission for examination) as states enact measures to reach the targets set.18 In turn, this alters the dynamics of national economics, which in conjunction with the continued primacy of states in the bilateral trade in energy resources is set to make much more visible impacts. Subsequently, these changes in energy consumption trends and the greater prioritisation of climate change as a policy issue is important for the EU's relationship with energy suppliers, including Australia.

It is clear that the dynamics of energy policy have not been clarified by the Lisbon Treaty, but continue to be plagued by issues of sovereignty and the unclear allocation of responsibility. The confluence of different actors inevitably creates complications in EU trade in energy resources. The fact that many of the aspects of energy trade must be negotiated between Member States with competing interests means that the impact of the Lisbon Treaty is not as strong as it might first appear. Instead, the greatest impact can be seen in the introduction of legislative imperatives which enforce changes to Member State policy, such as the CEP. It is through those changes that dynamics of EU trade in energy resources with third parties are altered.

\section{The Australian system and EU-Australian trade relationship}

Before discussing the dynamics of EU-Australia energy trade, it is useful to understand the basis of Australian climate change and energy policy. This provides a counterpoint to the EU's climate and energy policy. The Australian government very recently secured the passage of the Clean Energy Legislative Package (CELP), which was passed by the

17 Commission of the European Communities, Directive 2009/ 28/ EC of the European Parliament and of the Council of 23rd April 2009 on the promotion of the use of energy from renewable sources and amending and subsequently repealing Directives 2001/ 77/ EC and 2003/30/ EC, OJ L 140, 5th J une, 2009.

18 Ibid, Article 4. 
Senate on the $8^{\text {th }}$ November, 2011.19 This package centres on the introduction of a carbon tax with a view to move to a flexible market-based emissions trading scheme (ETS) in coming years. ${ }^{20}$ This complements and provides a much stronger legislative backing to other climate change initiatives, such as the Renewable Energy Target (RET). The RET was introduced in 2009 as a means to reach the government target of $20 \%$ of all electricity to come from renewable energy sources by 2020.21 Thus there is a degree of similarity between the EU and Australia's approach to climate change, although Canberra is less ambitious in the scope of its policies, while Brussels is a leader in this area.

However, there is also a significant tension for Australia in reconciling climate change efforts with the reality of its energy industry. The Australian government is in the process of developing a new White Paper on Energy for release in 2012, replacing the one released in 2004.22 The new White Paper will incorporate amongst other documents and consultations, aspects of the 2009 National Energy Security Assessment (NESA) which encompasses a wide range of issues including energy mix, investments, etc. ${ }^{23}$ It is not possible to include all of the NESA's analysis in this article but it is worth noting the stress it places on the growth of Australian LNG, continuing an emphasis on Australia's role as a net energy exporter. ${ }^{24}$ As such, examination centres on Australian exports to the EU, which constitutes the fundamental dynamic of EU-Australia energy resources trade. Australia's energy exports revolve around natural gas, uranium and coal and as such this predominance of fossil fuels leads to problems between climate change and energy policy priorities. ${ }^{25}$ The Australian government is trying to reconcile this via greater investment and research into Carbon Capture and Storage (CCS) through a series of flagship programs, to try ensure the ongoing viability of the Australian fossil fuel industries despite their high emissions and the fact that the money invested could be used for renewable energy projects. ${ }^{26}$. This helps to maintain an export market for Australian energy and satisfy a key aspect of Canberra's energy policy. This is particularly emphasised in the case of coal with the introduction of programs to offset the costs of the CELP, such as the Coal Sector J obs Package (CSJ P) and the Coal Mining

\footnotetext{
19 Department of Climate Change and Energy Efficiency, Clean Energy Legislation, Commonwealth of Australia, <http:// www.climatechange.gov.au/government/ clean-energy-future/legislation.aspx> accessed 29 November, 2011.

20 Commonwealth of Australia, Clean Energy Act, 2011, Act 131 of 2011, Part 1, Section 4.

21 Australian Parliament Parliamentary Library, Renewable Energy Target (RET),

<http:// www.aph.gov.au/ library/ pubs/ climatechange/ governance/ domestic/ national/mandatory.htm>, accessed 29 November, 2011.

22 Department of Resources, Energy and Tourism, Energy White Paper Process - Update,

Commonwealth of Australia, <http:// www.ret.gov.au/ energy/ Documents/ ewp/ factsheet/ EWP-

Factsheet-Update.pdf>, accessed: 30 November, 2011,p. 1.

23 Ibid: 2; Department of Resources, Energy and Tourism, National Energy Security Assessment - 2009, Commonwealth of Australia, (Canberra: 2009).

24 Department of Resources, Energy and Tourism, National Energy Security Assessment - 2009, op.cit. 16-19.

25 Department of Resources, Energy and Tourism, Energy in Australia - 2011, Commonwealth of Australia, (Canberra: 2011): 1-2.

26 Department of Resources, Energy and Tourism, Carbon Capture and Storage Flagships Program, <http:// www.ret.gov.au/ energy/ Documents/cei/ccsfp/CCS_Fact_Sheet-J une-2011.pdf>, accessed 30 November, 2011. 
Abatement Technology Support Package (CMATSP). ${ }^{27}$ The fact that the government offsets the coal sector which is one of the most polluting and is therefore ostensibly one of the targets of CELP indicates the importance of the coal sector to Australia and highlights the inconsistency between its energy and climate change policies. Therefore through this continued emphasis on policies to support fossil fuel industries we can see an inherent tension between Australian energy and climate change policies even if there are attempts to reconcile the two to some degree. Having noted this ongoing tension between these two policy areas and having addressed the role of exports in Australian energy security, the section continues with an examination of EU-Australia trade in coal, uranium and gas and investigates how EU climate change policies may impact this.

Currently, the EU-27 is Australia's largest trade and investment partner, constituting $15.2 \%$ of Australia's total trade in goods and services. ${ }^{28}$ In 2009, total trade in goods and services between the EU and Australia reached approximately AUD\$77.2 billion. ${ }^{29}$ Although this was a slump of $16 \%$ due to the Global Financial Crisis, trade has on average increased by $5.6 \%$ per annum. 30 This makes the EU a crucial partner for Australia and one whose internal dynamics make themselves felt in the relationship, particularly in terms of trade revenue including from energy.

In 2009-2010, Australia was the ninth largest energy producer in the world, supplying approximately $2.4 \%$ of world energy with its main resource exports being coal, uranium and natural gas. ${ }^{31}$ Australia is estimated to hold approximately $22-47 \%$ of total world uranium reserves and $10 \%$ of world coal reserves. ${ }^{32}$ Since the late 1980s, the value of energy exports in Australia has increased by $11 \%$ per year on average, with energy resources making up 33\% of total commodity exports for Australia in 2008-09.33 Furthermore, in the same period, energy exports accounted for $68 \%$ of total domestic energy production. ${ }^{34}$ Australia also remains the largest coal producer in the world, creating export earnings of AUD\$55 billion in 2008-09 and supplying 28\% of world's coal. ${ }^{35}$ This demand is increasingly coming from the developing Asian economies,

27 Department of Resources, Energy and Tourism, Clean Energy Package - Australia's Coal Sector, J uly, 2011 http:// www.ret.gov.au/ Department/ Documents/ clean-energy-future/ COAL-FACTSHEET.pdf, (last accessed: 28th November, 2011).

28 Department of Foreign Affairs and Trade, Australia's Trade with the European Union - 2009,

Commonwealth of Australia, <http:// www.dfat.gov.au/publications/ stats-pubs/ Australia-trade-withthe-EU-2009.pdf>, accessed: 18 November, 2011, p. 1.

29 Department of Foreign Affairs and Trade, Australia's Trade with the European Union - 2009, op.cit.:1.

30 Department of Foreign Affairs and Trade, Australia's Trade with the European Union - 2009, op.cit., 1.

31 Department of Resources, Energy and Tourism, Energy in Australia - 2011, op.cit.: 1.

32 Department of Resources, Energy and Tourism, Energy in Australia 2011, op.cit., 4.; Market

Observatory for Energy, Country File - Australia, Commission of the European Communities,

$<\mathrm{http}$ // ec.europa.eu/ energy/ observatory/doc/ country/2011_02_australia.pdf>, accessed: 29 November, 2011.

33 Department of Resources, Energy and Tourism, Energy in Australia - 2011, op.cit.: 1-3.

34 Department of Resources, Energy and Tourism, Energy in Australia - 2011, op.cit: 1.

35 Australian Coal Association, "The Australian Coal Industry - Coal Exports,"

$<\mathrm{http}: / /$ www.australiancoal.com.au/the-australian-coal-industry_coal-exports.aspx> accessed 12th

January, 2011. 
notably China and India; however, the EU's own demands are also increasing with demand and are projected to have risen $5 \%-9 \%$ by 2020.36

According to a European Commission Working Paper accompanying the Second Strategic Energy Review, 13\% of total EU coal imports are sourced from Australia. This is a significant proportion considering the geographical distance. By way of comparison Russia, which is geographically much closer to the EU, accounted for $26 \%$ of EU coal imports. ${ }^{37}$ Although the proportion of Australia's coal exports sold to the EU appear relatively small, the level of earnings remains significant at AUD $\$ 2.479$ billion in 2009.38 When one considers that total coal exports to the EU dropped in 2009 by 60\%, the one year aberration becomes apparent. ${ }^{39}$ Indeed this is well demonstrated by EU figures which show that in 2009, EU imports of Australian coal dropped constituting only $4.2 \%$ of total EU coal imports. ${ }^{40}$ This is made even more explicit when one notes that coal exports to the EU in 2010 rose $57.5 \%$ on 2009 levels to AUD\$3.9 billion. ${ }^{41}$ Furthermore coal is consistently ranked as one of the top exports to many of the EU Member States including the major economies, consistently ranking in the top 3-4 places in terms of value of exports. ${ }^{42}$ Thus the value of the ongoing trade in coal is of high importance for both the EU and Australia not only in monetary terms but also as a source of diversity of markets. The importance of energy trade for Australia also extends to nuclear fuels and natural gas.

Uranium is an important resource in the trade relationship, with Australia supplying $22 \%$ of the EU's total uranium imports. ${ }^{43}$ In contrast, although Australia is one of the largest producers of Liquefied Natural Gas (LNG), natural gas does not represent a major Australian import in the EU. Natural gas represents a significant Australian export especially in the Asia-Pacific. With the current levels of investment production is projected to continue to increase over time. ${ }^{44}$ Indeed, between 2005-2010, the total average annual increase in value of LNG production was $21.8 \% .{ }^{45}$ When including the additional reserves from new discoveries and expanded capabilities in extraction,

\footnotetext{
36 Commission of the European Communities, “Europe’s Current and Future energy position - Demand - resources - investment," SEC(2008) 2871, 13.

37 Commission of the European Communities, Europe's Current and Future Energy Position, op.cit: 9. 38 Department of Foreign Affairs and Trade, Australia's Trade with the European Union - 2009, op.cit.: 60 .

39 Department of Foreign Affairs and Trade, Australia's Trade with the European Union - 2009, op.cit.: 3. 40 Market Observatory for Energy, Country File - Australia, op.cit: 12.

41 Department of Foreign Affairs and Trade, Australia's Trade with the European Union - 2010 , Commonwealth of Australia, <http:// www.dfat.gov.au/ publications/ stats-pubs/ Australia-trade-with-theEU-2010.pdf>, accessed 28 November, 2011, p.3.

42 Department of Foreign Affairs and Trade, Australia's Trade with the European Union -2010, op.cit.: 64-90.

43 Market Observatory for Energy, Country File - Australia, op.cit.: 12.

44 Department of Resources, Energy and Tourism, Australian Liquefied Natural Gas,

<http:// www.ret.gov.au/resources/upstream_petroleum/australian_liquefied_natural_gas/pages/ home. aspx> accessed: 28 November, 2011; Reserve Bank of Australia, "The Iron Ore, Coal and Gas Sectors," Bulletin, March Quarter, 2011, <http:// www.rba.gov.au/publications/ bulletin/2011/ mar/ 1.html\#f4>, accessed 1 December, 2011.

45 Reserve Bank of Australia, “The Iron Ore, Coal and Gas Sectors,” op.cit.
} 
Australia, according to the International Energy Agency (IEA) could become the third largest gas producer in the Organisation for Economic Cooperation and Development (OECD), supplanting Norway and just behind Canada and the United States. ${ }^{46}$ Despite this potential, at present EU-Australia trade in gas is negligible at best, totalling only AU\$61 million in 2009, with no trade recorded in 2010.47 Instead, Australian LNG is almost entirely destined for Asian markets, predominately J apan who accounts for $70 \%$ of the total with China's demand increasing also. ${ }^{48}$ Thus, coal and uranium constitute the most important sectors in EU-Australia energy trade. This article will now examine how shifts in EU energy policy and climate change priorities may affect the balance and nature of the trade.

\section{A Gravitational pull: the effects of EU policies and circumstances on Australian energy exports}

Given these important aspects of the trade relationship, any changes to the internal energy policy dynamics in either one of the parties will have important ramifications on trading relationship. The rapid fall in value of coal exports to the EU after the GFC is a good example of this. The 60\% drop in coal exports to the EU coupled with the fall in world commodity prices created a significant negative impact upon the Australian coal industry and had a profound negative impact on the country's economy. Prior to the GFC, the 2008 trade in coal was over AUD $\$ 6$ billion and rising steadily. ${ }^{49}$ With the GFC and the resultant $60 \%$ drop in EU demand for coal, Australian export earnings dropped to only AU $\$ 2.5$ billion. ${ }^{50}$ Although the dynamics of the GFC were the primary contributors to this rapid fall in trade, it shows the impact that changes in trade partners domestic situations can exert on the overall value of trade, with particular ramifications for certain industries. Therefore the introduction of the CEP as a considered, developed policy with a strong legal basis is set to have important consequences for the ongoing EU-Australia trade in energy resources.

The CEP is predicated on the need to address climate change through a greater emphasis on renewable sources of energy and lowering EU energy intensity and Greenhouse Gas (GHGs) emissions. As an integral part of this, the EU aims to lower its dependence on fossil fuels for energy production and, by extension, reduce its import dependence. This has serious consequences for the Australian economy, given the high value exports that currently travel to EU markets and this change could potentially undermine an important source of revenue earnings for Australia.

The aims of the CEP to reduce dependence on fossil fuels and lower GHGs limit the ongoing viability of exports of coal to the EU in particular. Given that coal is the most polluting of fossil fuels in terms of GHGs output, the potential for continued implementation of coal-fired power becomes less certain. Compared to other energy

46 International Energy Agency, World Energy Outlook - 2010, (Paris: OECD/ IEA, 2010): 192.

47 Department of Foreign Affairs and Trade, Australia's Trade with the European Union -2010, op.cit.:4.

48 Reserve Bank of Australia, "The Iron Ore, Coal and Gas Sectors," op.cit.

49 Delegation of the European Union to Australia and New Zealand, "EU-Australia Economic

Relationship, EU Insight, October 2009, (last accessed 28th November, 2011).

50 Department of Foreign Affairs and Trade, Australia's Trade with the European Union - 2009, op.cit: 3. 
resources, coal generates $755 \mathrm{gCO} 2 / \mathrm{kWH}$ whereas gas is approximately $385 \mathrm{gCO} 2 / \mathrm{kWH}$ with nuclear power much lower at $1-22 \mathrm{gCO} / \mathrm{kWH} .{ }^{51}$ In order to ensure that the EU meets its own 20-20-20 targets, the energy industry, particularly coal, is facing important challenges and uncertainty in the direction EU governments will take. This is largely because the CEP and broader EU energy policies stress the sovereignty of Member State governments over the broad content of their energy mix. The policies relating to energy mix and climate change are to be of most consequence for Australia. Subsequently, the decisions by individual Member State governments in pursuit of the goals in the CEP will be critical to the EU-Australia energy trade. For instance, in the financial year 2008-09, the Netherlands, the United Kingdom and France were the biggest importers within the EU of Australian coal, both metallurgical and thermal. ${ }^{52}$

Table 1: Australian coal exports to selected EU member-states ${ }^{53}$ :

\begin{tabular}{|l|l|l|l|l|}
\hline Destination & $\begin{array}{l}\text { Metallurgical } \\
\text { Volume } \\
\text { million tons }\end{array}$ & $\begin{array}{l}\text { Thermal } \\
\text { Volume } \\
\text { million tons }\end{array}$ & $-\begin{array}{l}\text { Total Coal } \\
\text { Volume } \\
\text { million tons }\end{array}$ & $-\begin{array}{l}\text { Percentage of } \\
\text { total exports } \\
(\%)\end{array}$ \\
\hline Netherlands & 3.6 & 0.6 & 4.2 & 1.6 \\
\hline $\begin{array}{l}\text { United } \\
\text { Kingdom }\end{array}$ & 3.9 & 0.1 & 3.9 & 1.5 \\
\hline France & 2.3 & 1.1 & 3.4 & 1.3 \\
\hline
\end{tabular}

The average values of coal exports in 2008-09 was AUD $\$ 221.58$ per ton. Thus, earnings from these three countries totalled AUD $\$ 2.5$ billon. 54 As a consequence, changes in these countries' energy policy may have important ramifications for Australian coal exports. When other EU countries' exports are included the potential ramifications become increasingly pronounced. As the changes stimulated in the national policies on climate change come from the EU level then, the changes are systemic throughout the EU and thus exports to the whole EU are altered. This affects all major industries as well as the energy industry. For example, energy-intensive industries such as steel are forced to reach greater energy efficiency and are faced with challenges under programs such as the ETS and the Integrated Pollution Prevention and Control (IPPC) Directive. These regulations are likely to have a strong impact on the steel industry. As Australia exports significant amounts of metallurgical coal to the EU as a fuel for steel-making, the impacts of these policies on the sector will have repercussions for the level and value of Australian coal exports.

However, there are a number of opportunities available to Australia, which should not be underestimated. However, before examining this, this article will show that the

\footnotetext{
51J an Willem Storm van Leeuwen, CO2 emissions from nuclear power in Secure Energy? Civil Nuclear Power, Security and Global Warming, edited by Frank Barnaby and J ames Kemp, (Oxford Research Group, March: 2007): 41.

52 Australian Coal Association, "The Australian Coal Industry - Coal Exports Details,"

$<\mathrm{http}$ // / www.australiancoal.com.au/ the-australian-coal-industry_coal-exports_coal-export-

details.aspx>, accessed 14 May, 2011.

53 Ibid.

54 Australian Coal Association, “Coal Exports Details,” op.cit.
} 
sovereignty of Member States also affects nuclear power and thus has a profound impact on Australian uranium exports.

Many countries in the EU continue to resist expanding nuclear power possibilities. For instance, Germany is planning on phasing out nuclear power by 2022 in response to the Fukushima crisis. ${ }^{55}$ On the other hand others such as France continue to base large proportions of their energy policy on such resources and Finland is commissioning another nuclear power plant at Pyhajoki. ${ }^{56}$ Nuclear power is also interesting in that it presents a means of generating power with much lower emissions than fossil fuels. Thus it has strong potential in terms of meeting the CEP targets. This may mean that EU climate change policy provides an export opportunity for Australia. If countries decide to continue or expand their use of nuclear power as a means of lowering fossil fuel use this could expand the range of markets for Australian uranium exporters. However, on the other hand the reluctance to use nuclear power by major economies such as Germany could cause problems.

The implementation of the CCS (and its promotion by the Australian government) is an important step in promoting the ongoing use of coal in EU power generation and the Steel Technology Platform (ESTEP) for the steel industry. In 2020 by 2020: Europe's climate change opportunity, the European Commission notes, "stocks of coal will be needed to provide energy in Europe." 57 The legislation for CCS endeavours is still highly limited but it is worth noting that the emergence of such developments provide are important to the EU energy policy's ongoing evolution. Additionally the ESTEP program provides a means to maintain and expand the steel industry, stimulating an ongoing need for coal. This article does not seek to embark on an analysis of either the CCS or ESTEP and their future potential but wishes to highlight how the implementation of such policies may have a beneficial impact for Australian coal exporters. Thus, although the effects of policy and circumstance in this article often address negative implications, particularly in the case of coal, changes can in fact also lead to opportunity even where some opportunities may be limited in scope.

Nonetheless it is important not to over-emphasise potential opportunities. This is particularly true for potential export of natural gas to the EU. As Poland and Germany, address the need to diversify their energy sources away from domestically sourced coal, in order to meet their GHG obligations under the Kyoto Protocol and the CEP, they are turning increasingly to natural gas as a short term solution. The comparably low level of emissions of natural gas compared to other fossil fuels such as coal makes it a highly useful transition fuel whilst the capacity and infrastructure of renewable energy sources is developed.

55 BBC, Germany: Nuclear power plants to close by 2022, BBC News,

<http:// www.bbc.co.uk/ news/ world-europe-13592208>, accessed 1 November, 2011.

56 Terhi Kihunnen, Finland names first nuclear site after Fukushima , Reuters, 5th October, 2011, <http:// www.reuters.com/article/ 2011/ 10/ 05/ us-finland-nuclear-idUSTRE7941VD20111005>, accessed:

1 November, 2011.

57 Commission of the European Communities, 2020 by 2020: Europe's Climate change opportunity,

$\operatorname{COM}(2008) 30$ final, (2008): 9. 
It could be argued that EU countries sourcing increasing levels of natural gas may provide an alternate market for the growing production of Australian LNG, mitigating current dependence on sales to Asian markets. However, the potential is extremely limited. The EU currently has long-term contracts with many suppliers much closer to its borders, Russia being the prime example. In addition, in Europe the majority of countries are linked to gas supplies via a system of pipelines that facilitate direct links between suppliers (such as Algeria and Russia). As a result, the cost of LNG (due to the liquefaction process) exports in conjunction with the vast distance of sending LNG to EU markets means that Australian natural gas exports are unlikely to be competitive. Therefore Australia's energy exports to the EU are likely to continue to revolve around uranium and coal, and, as part of this, Member State decisions under the CEP and also on the nuclear issue are of pressing concern.

Therefore it becomes apparent that the legislative changes and the resultant individual government policies exercise a direct impact upon the scope of Australian energy exports to the EU. Of course, such policy changes and legislative arrangements are not intended to exert such an influence, but they nevertheless serve to demonstrate the impact of an interdependent trade relationship with all the associated sensitivities. Although EU-level policy exercises influence, supra-national developments are not themselves instigators of change in the EU-Australian trade in energy resources. It is the domestic policy developments, which occur as a consequence of, in response to, and also independently of EU developments that exercise the greatest influence EU-Australian trade. Domestic policy changes and associated aspects of the bilateral trade between Member States and Australia have the greatest impact on trade.

\section{Conclusion}

The Lisbon Treaty introduced fundamentally important changes to the way in which the EU conducts itself on the world stage and into the EU's decision-making process. In addition, it clarified the delineation of responsibilities in certain areas. However, this was not the case for energy policy. Instead the treaty included energy as a shared competence but simultaneously failed to provide clear direction about the individual areas of responsibility. Given the EU's growing dependence on imports of energy resources, this omission creates an inherently unstable policy arena, especially given the crucial overlap between energy and foreign and security policies of the Member States. In conjunction with emphasis on Member States determining their own energy mix and energy sources, this perpetuates Member State dominance in energy matters. The continued dominance of Member States means that trade in energy resources is still conducted primarily on a bilateral basis, with only a limited avenue for direct EU institution involvement. The EU exercises important controls in energy policy by virtue of its competence over the Internal Market, and also through the enforcement of policies such as the CEP originally negotiated by the Member State governments in the Council. The introduction of the CEP saw the establishment of legislation that has necessitated individual Member States to adapt their own energy policies to meet - amongst other goals - the necessary emissions reductions targets. In turn, this has cast doubt on the ongoing viability of coal and uranium exports from Australia to the EU, as issues such as energy mix come to the forefront of energy policy planning. Despite the potential for 
negative ramifications, new opportunities have also emerged, which could at least partially offset the detrimental impacts of this policy change. Uranium trade appears to be quite stable and the continued preference for nuclear power by certain countries should ensure the ongoing viability of this aspect of the trade relationship, even if other countries shift away from nuclear energy. In contrast, the relative lack of gas trade makes it extremely unlikely that EU policy changes will have any significant impacts on Australia since the cast majority of Australian LNG goes to Asia. As such, the importance of Member State decisions about their energy mix becomes a clear, defining characteristic and an influential mechanism in EU-Australia energy trade.

Therefore, through its capacity to influence the priorities of national governments via legislative measures the EU has a significant impetus in influencing EU-Australia trade. By stimulating national governments to adjust their energy mixes and overall energy policy in response to changing EU and world dynamics, they invariably impact on the level and value of coal and uranium needed to satisfy domestic economic imperatives. However, it is the governments themselves who decide how they should respond to and satisfy EU requirements. It is these smaller more focused national aspects within the overall EU energy policy dynamics that have the greatest impact on the EU-Australia energy trade. 